\title{
FUEL PRICES AS A FACTOR OF SHAPING PROFITABILITY OF ROAD TRANSPORT IN POLAND
}

\author{
Lukasz Marzantowicz
}

University of Szczecin, Department of Logistics, Poland,lukasz.marzantowicz@wzieu.pl

\begin{abstract}
The goal of this article is to determine the relation between the price of fuel and the profitability of the company. For this purpose, the article defines the profitability of transport enterprises and points the source of the impact of changes in fuel prices on the profitability of companies in the road transport sector. The case of the $\mathrm{ABC}$ transport company shows the relationship between the costs incurred for the purchase of fuel and the cost of transport activities. To test the theoretical assumptions, case study method was used.
\end{abstract}

Keywords: fuel prices, the profitability of road transport companies, the share of fuel costs in the profitability of companies

Type of the paper: Theoretical paper, Case study

JEL Classification: M21

\section{Introduction}

At this time, market of road transportation services in Poland is facing economic problems similar to other European countries. One of the elements that affects the level of profitability of a transport company the most is fuel price. From the economic point of view, the costs incurred during the process of purchasing the fuel are an important part of the companies' budget. In general, the fuel prices play a huge role in the overall financial planning of the company. In order for the company to reach the breakeven point, the cost of the fuel must be lower or equal to the income of the company that occurs during the physical year.

Furthermore, this article reviews the impact that fuel prices have on the profitability of the company. Fuel price component not only measures the profitability of the company but can also determine the path of the development.

The goal of this article is to determine which relations are formed between the price of fuel and the profitability of the company. The article also answers the questions to what extent the fuel cost influence the profitability of the company?

The article describes a case of the ABC company. The analysis of this case allows looking in a practical way at the use of indicators of profitability and also contributes to the search for new directions of research and development in economy.

\section{The relationship between the price of fuel and the profitability of transport companies in Poland}

From the point of view of economics of transport, higher profit is generated by lower fuel prices. According to this statement, the question arises: What level of profitability is satisfactory for transportation companies and how the price of fuel compared to an operating profit can be called effective? In the cost structure of transportation activities (excluding salaries and the cost of purchase and maintenance superstructure, but these, even though high, are occasionally), fuel price is one of the most cost absorbing elements. Fuel prices are also an important component of the budgets of companies operating in other sectors of the economy. Because, in general, transport is not only a stimulator of the economy but often the flywheel economic activity. 
In order for the company to pursue the main purpose of transportation activities, the purchasing of the fuels should be considered as a primary element. It is a key component of the gain. The functioning of carriage without the fuel is completely impossible. Fuel prices are very important not only in terms of achieving profit but also they

- Control the rate of flow of materials and services,

- Affect the shape of the price of the final product and services,

- Shape the demand and supply of transport services,

- Affect the efficiency of freight and passengers,

- Delimitate the income dynamics of transport companies,

- Are often the determinant and the reason for the cessation of transport operations.

It is important to understand how the carriage of goods in Poland is formed. This is an important factor, especially if one takes to consideration the level of profitability of freight at the national level (macro). The structure of transported goods is the result of transportation defined as profitable - in this case, economically justified (for companies). Structural approach of goods transported by road in Poland are presented in Table 1. The data in Table 1 are the percentages of recognition of the volume of cargo transported by land, whereas the quantification of freight over the years 2003-2013 is shown in Fig. 1.

Table 1. The structure of freight transport by road transport by group of goods in 2013. (source: author's compilation based on 'Transport wyniki działalności w 2013', 2014)

\begin{tabular}{|l|c|}
\hline Type of transported goods & $\begin{array}{l}\text { Share } \\
(\%)\end{array}$ \\
\hline Metal ores and other mining and quarrying products & 29.2 \\
\hline Production of other non-metallic materials including lime, cement, gypsum and building materials & 13.4 \\
\hline Food, beverages and tobacco products & 9.9 \\
\hline Secondary raw materials and waste & 8.4 \\
\hline Products of agriculture, hunting, forestry, fishery and fishing & 6.5 \\
\hline Wood and products of wood and cork (not furniture), articles of straw, paper and paper products & 6.1 \\
\hline Metals and fabricated metal products (except for machines and devices) & 5.1 \\
\hline Chemicals & 4.1 \\
\hline Coke and refined petroleum products & 3.2 \\
\hline Coal and lignite, oil and natural gas & 2.3 \\
\hline Transportation equipment & 1.8 \\
\hline Machinery, equipment, electrical and electronic equipment & 1.5 \\
\hline Empty containers and packaging & 1.4 \\
\hline Furniture and other finished products & 1.2 \\
\hline Textiles and garments, leather and leather products & 0.3 \\
\hline Others & 5.6 \\
\hline
\end{tabular}

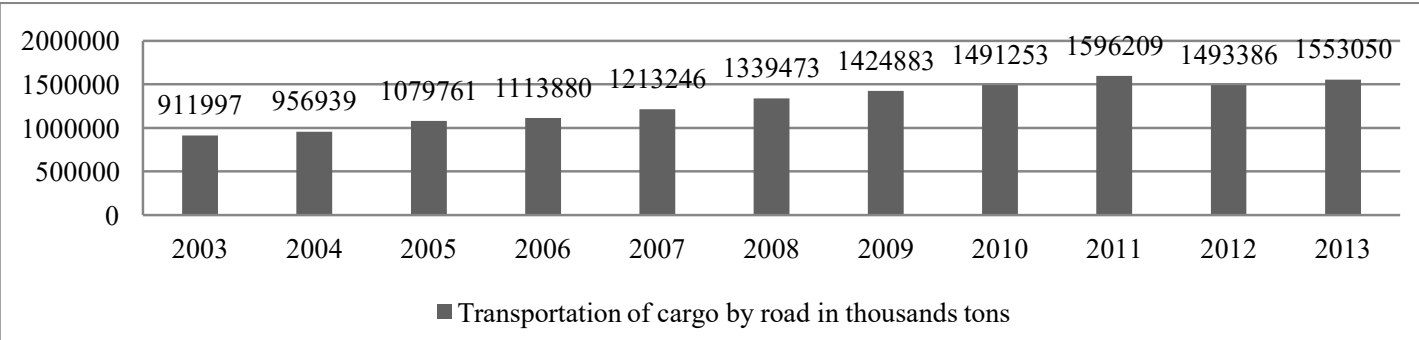

Figure 1. Transportation of cargo by road transport in thousand tonnes. (source: author's compilation based on 'Transport wyniki działalności w 2013r', 2014)

There are two aspects in which profitability of transportation and the level of profitability of transport companies should be considered. First is the supply, where profitability is understood as the ability to 
increase the revenue by the company based on internal factors (such as infrastructure and suprastructure of the company meets the needs of the market) and external factors, such as fuel prices. The second aspect is the issue of demand. Demand for transport services, in fact, generates dynamic changes in the profitability of the company.

The cost of fuel has a big impact on the level of profitability of the company. Profitability itself helps determine the financial results of the company. If the result is positive, the company is profitable; if the result is negative, the company is facing deficit (Bednarski, 2001). Profitability plays a huge role in determining whether the project will bring profit or loss. At this time, one must define breakeven point. That breakeven point allows a transportation company to determine how much work should be put into the project for the incurred costs to be covered by $100 \%$, so everything that the company reaches above the threshold should be called profit (Engelhardt, 2014). At the same time, one can use the catalogue of formulas to calculate the breakeven point of the company. The choice, however, depends on the accuracy of the result, which the enterprise wants to get. Catalogue of profitability's ratios is shown in Table 2.

Table 2. Catalogue of profitability's ratios (source: author's compilation based on Engelhardt, 2014)

\begin{tabular}{|c|l|l|c|}
\hline No. & \multicolumn{1}{|c|}{ Type of ratio } & \multicolumn{1}{|c|}{ Quotient } & Value of percentage \\
\hline 1 & Profitability ratio 1 & The financial result/datum & - \\
\hline 2 & Profitability ratio 2 & The financial result/datum & $\times 100$ \\
\hline 3 & Sales profitability ratio & Financial result/revenues & $\times 100$ \\
\hline 4 & ROE & Financial result/capital & $\times 100$ \\
\hline 5 & ROE total 1 & Net result/equity total & $\times 100$ \\
\hline 6 & ROE total 2 & Net result + interest/total capital & $\times 100$ \\
\hline 7 & Net profit margin equity & Net result/equity & $\times 100$ \\
\hline 8 & Gross profit margin equity & Result before tax/equity & $\times 100$ \\
\hline 9 & Return on equity capital & Net profit/share capital & $\times 100$ \\
\hline 10 & ROE DC & Return on permanent capital/fixed capital & $\times 100$ \\
\hline 11 & Return on assets & Financial result/assets & $\times 100$ \\
\hline 12 & Net profit margin assets & Net profit/total assets & $\times 100$ \\
\hline 13 & Gross profit margin assets & Result before tax/total assets & $\times 100$ \\
\hline 14 & Gross profit margin assets & The result before tax + interest/total assets & $\times 100$ \\
\hline
\end{tabular}

The main component of profitability ratios is always the financial result. The financial result should reflect/be based on/contains the difference between the achieved revenue and costs incurred during the period (Formula 1).

$$
W_{\mathrm{f}}=P-K
$$

where

$W_{\mathrm{f}}$ is the financial result in the period

$P$ is the revenues in the same period

$K$ is the costs during the same period

By using the formula 1 and taking into account other internal and external factors, one can determine the basic types of financial result (depending on the data used):

- Gross profit,

- Net financial result,

- Financial result of economic activity, 
- Financial result from operations, that is, EBITDA (operating financial result before interest, taxes, depreciation and amortisation)

- Financial result EBIT (financial result, taking into account internal and external costs and other income)

- EBTEI financial result (financial result resulting from company's strategy, it does not contain, as the occurrence of extraordinary events, which can not be predicted)

- Financial result EBT (financial result before taxes including company events that do not occur frequently and are associated with the risk of doing business)

- Financial result from the sale,

- Financial result of manufacturing services and so on.

In most enterprises, the threshold of profitability and the level of profitability is determined by the use of at least a few indicators. This is due to the fact that it is possible to conduct the analysis of profitability based solely on the final results (net profit). At the end, the final profit is affected by many factors and events.

To originate the relation between fuel prices and the level of profitability of Polish road transport companies, one needs to take into consideration the data on changes in fuel prices over several years. This allows you to notice/understand the impact of fuel prices and the actual share in the cost structure of the company. To see the dynamics of changes in the prices of motor fuels in Poland in the years 2009-2014 refer to Fig. 2.

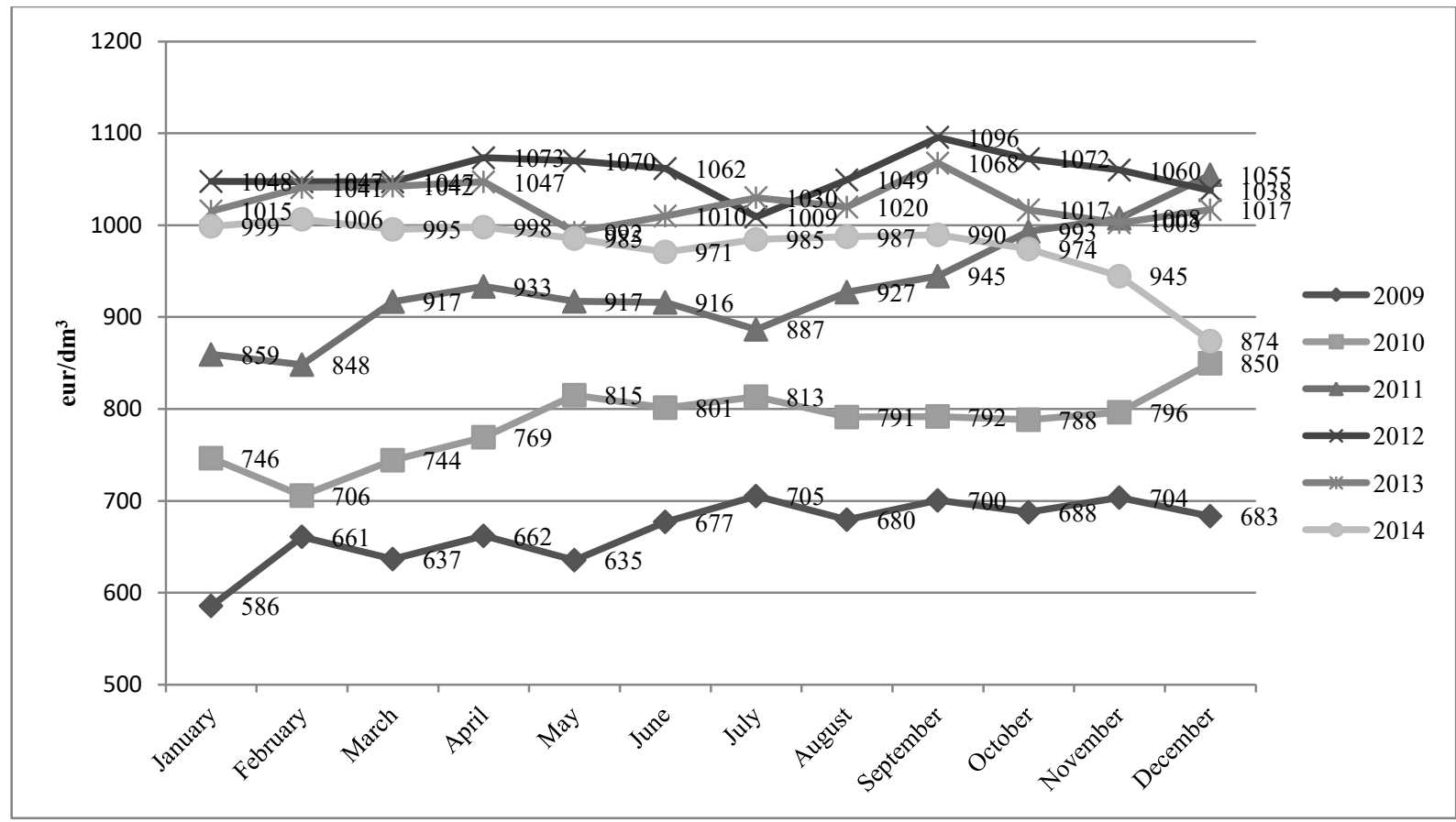

Figure 2. Decomposition of wholesale fuel prices in 2009-2014 (source: author's compilation based on PKN Orlen 2009-2014).

One should keep in mind that the Polish zlotys depends on the price of the dollar. Because the dollar is accounted for transactions involving the purchase of crude oil, the relation between the fuel prices and the profitability of the transportation company depends not only on the current exchange rate of the dollar but also on the relation resulting from seasonality (fuel in Poland is more expensive during the holidays). This relation is also impacted by factors related to the legal situation in the conduct of the transport business, economic and political situation - especially in the purchase and supply of crude oil, taxes, employment in the oil sector and other external factors related to the transport sector of the economy.

In the strict sense, the relationship between the price of fuel and profitability can, therefore, be demonstrated by Fig. 3 . 


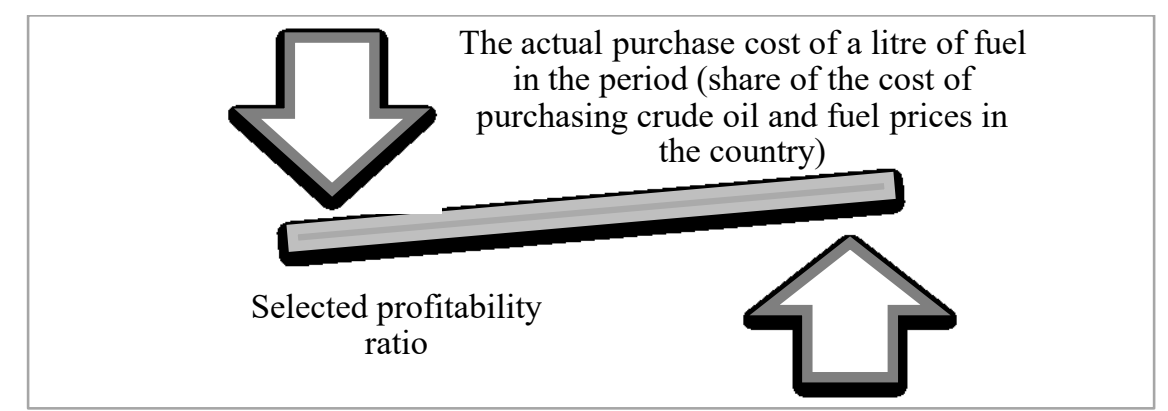

Figure 3. Schematic relationship between the price of fuel and the profitability of transport companies (source: author's compilation)

In the relation between the price of fuel and the profitability, there is an obvious phenomenon of proportional changes. If the price of fuel drops, the profitability of transport company increases. In other words, the income earned above the profitability rate determines the level of the profit of company.

\title{
The share of fuel costs in the profitability of transport companies in Poland
}

Road transportation in Poland is a branch with the largest market share amongst all modes of transport. The Polish market does not differ in its structure from other European countries. Issues related to costs of transport activities are also similar, especially in terms of the impact of fuel costs on the profitability of the company. It is worth mentioning that the road transportation has the largest presence within the other sectors of transport. Bimodal transport system in the vast majority consists of road transportation (delivery and drop off) and other modes of transport. The share of road transportation in the transport market is presented in Fig. 4.

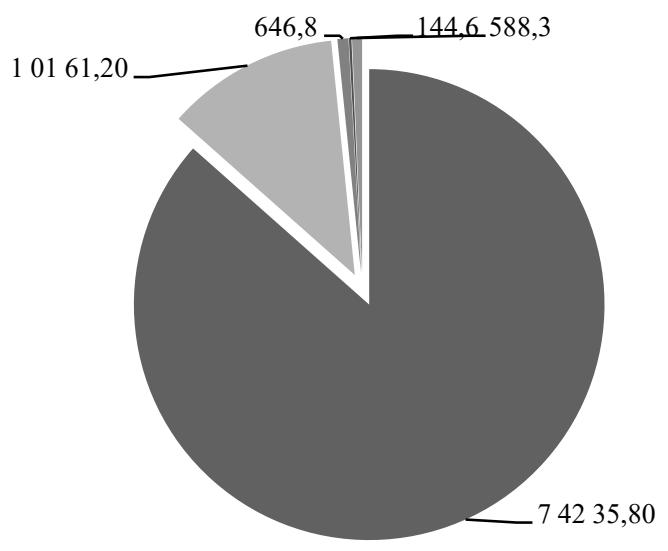

\author{
Car transport \\ Other land transport in the pipeline \\ Air transport \\ - Inland water transport \\ Maritime transport
}

Figure 4. Revenues of transport enterprises by mode of transport (source: author's compilation based on 'Transport wyniki działalności', 2013).

The revenue/profit/income earned per vehicle per kilometre is one of the best kept secrets of transportation companies; it is hard to distinguish how much and for what the company receives the most revenue. Mainly, all of it depends on how much and where the carrier transports. However, based on the collected data, one can conclude that the common rate for transporting a full load trailer-type semi-trailers is approximately 1.10 euro $/ \mathrm{km}$. For carriers, this is the rate that is sufficient to cover the cost of transportation per kilometre. It is common that the employer will not get the whole load, and then the rate is lower. To take advantage of this solution, the company should conduct the partial load transfers more often. The company can wait for an order from the shipping or use another forwarding 
or keep track of freight exchange, where you can find the same order. Over the past few years, in Poland and other European countries, toll recorded an increase in prices. This caused a decrease in the desire to borrow (for investment and working capital) and leases by transport companies. As a result of the increased tolls, an intensive search for the possibility of reducing operating costs has begun. Cost incurred per vehicle per kilometre in the period from 2009 to the present time has increased on an average by around 27\%, which is illustrated in Fig. 5.

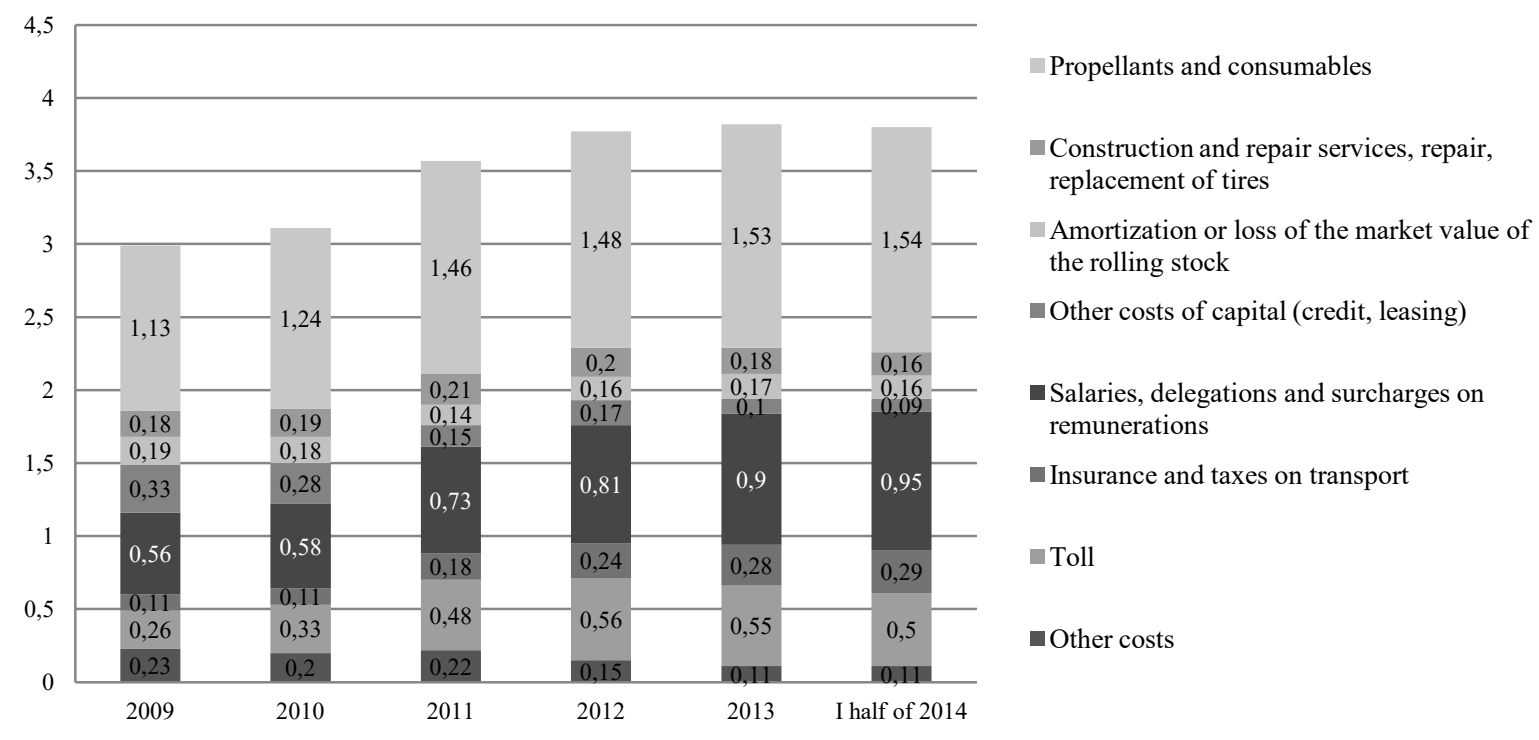

Figure 5. The structure of the cost of one vehicle kilometre for rolling over 12T in the years 2009-2014 (source: author's compilation based on Instytut transport samochodowego, 2015)

It is estimated that the share of fuel costs in the profitability of transport companies is more than $50 \%$ of the cost of that activity. As already mentioned, the transport sector has the possibility of doing business with the purchase of fuel. Therefore, despite the high share of fuel costs in the operating results, company does not have the ability to reduce these costs. Such a high share of fuel costs can not only limit the development of the core business but also contribute to a number of other significant problems in terms of competitiveness, cooperation and problems of outsourcing - the use of subcontractors service becomes unprofitable.

\section{The impact of diesel prices on the profitability of the company ABC transport - Case Study}

The ABC Transport company is a medium-sized transport company, which employs 10 drivers and 5 support staff members, that is, 2 porters, 1 mechanic and 2 office workers. The company was founded in 1993, and its headquarters are located in Mysliborz, near the border crossing in Krajnik Dolny (approximately $55 \mathrm{~km}$ ). Currently, its fleet consists of 10 Scania tractors with trailers type semitrailers. The company provides its transportation services in Poland and abroad. The most common transfers are conducted between Poland and Germany, Germany-Poland, and also within Polish territory, conducting domestic orders. Occasionally, the company provides its services between Poland and Netherlands, Belgium or France. ABC Transport is based in Hamburg and provides services to Polish transportation companies, giving orders from Germany to Poland. Orders generated in the country as well as abroad are executed by their own employees/shippers. The boss, who is also the owner of the company, provides all the support to the drivers. All the instructions and schedules are prepared and managed by the co-owner and chief decision-maker in financial matters. In addition to their own cars, the company's assets include a building, in which there is an office. The company also owns a parking lot area of 25 acres. The parking lot is designated to accommodate the space for the 
trucks and utility building that is used as a workshop. It also contains a small concierge desk, where the guard stands.

To determine the profitability of the company described in the case of $\mathrm{ABC}$, the following assumptions have been made:

- $4.20 \mathrm{zl}$, average exchange rate of the euro in 2009

- $32 \mathrm{l} / 100 \mathrm{~km}$, an average combustion of diesel fuel by trucks laden

- $291 / 100 \mathrm{~km}$,- an average combustion of diesel fuel by trucks without cargo

- $\quad+20 \%$ of total kilometres driven on empty

- $50 \%$ of full 'kilometres' driven by motorways (in Germany)

- 0.183 euro cents per kilometre motorway in Germany

- $11 \%$ of all freight, rate of pay for employees

- $20 \%$ straight-line depreciation rate

- $19 \%$ the amount of income tax

The calculation is based on the data from years 2009-2014. This is the basic data (revenue and capital), which allows to view the use of indicators of profitability, as shown in Table 3.

Table 3. Business details of $\mathrm{ABC}$ Transportation necessary to calculate the profitability in euro (source: author's compilation)

\begin{tabular}{|l|l|l|l|l|c|c|c|}
\hline No. & years & Revenue & Gross profit & $\begin{array}{l}\text { Net financial } \\
\text { result }\end{array}$ & $\begin{array}{l}\text { The value of } \\
\text { fixed assets }\end{array}$ & Equity capital & $\begin{array}{l}\text { Foreign } \\
\text { capital }\end{array}$ \\
\hline 1. & 2009 & $1,018,270.00$ & $282,513.92$ & $228,836.28$ & $886,142.86$ & $1,203,942.493$ & $112,095.24$ \\
\hline 2. & 2010 & $1,016,400.00$ & $298,951.84$ & $242,153.13$ & $762,333.33$ & $1,502,894.355$ & $26,380.95$ \\
\hline 3. & 2011 & $1,018,490.00$ & $272,554.19$ & $220,768.89$ & $638,523.81$ & $1,775,448.519$ & 0.00 \\
\hline 4. & 2012 & $1,061,500.00$ & $246,739.26$ & $199,858.80$ & $514,714.29$ & $2,022,187.781$ & 0.00 \\
\hline 5. & 2013 & $1,029,600.00$ & $244,137.65$ & $197,751.50$ & $390,904.76$ & $2,266,325.429$ & 0.00 \\
\hline 6. & 2014 & $1,002,320.00$ & $398,140.17$ & $303,207.82$ & $267,095.24$ & $2,640,656.071$ & 0.00 \\
\hline
\end{tabular}

Equity is the total value of equity from January 2014 with the financial results net each year, whilst foreign capital was a loan, which in 2010 were fully repaid. Repayment of loans had no major impact on the growth of the financial result. The biggest impact was on amortisation of the means of transport in 2013.

Profitability ratios in the period 2009-2014 are presented in Table 4 and Fig. 6.

Table 4. Profitability ratios of ABC Transport in individual years (source: author's compilation)

\begin{tabular}{|c|c|c|c|c|c|c|c|}
\hline Years & $\begin{array}{c}\text { Sales } \\
\text { profitability } \\
\text { ratio (\%) }\end{array}$ & $\begin{array}{c}\text { Ratio of } \\
\text { gross } \\
\text { profitability } \\
\text { of total } \\
\text { capital (\%) }\end{array}$ & $\begin{array}{c}\text { Net return } \\
\text { on equity } \\
\text { ratio of } \\
\text { total (\%) }\end{array}$ & $\begin{array}{c}\text { The gross } \\
\text { rate of } \\
\text { return on } \\
\text { equity (\%) }\end{array}$ & $\begin{array}{c}\text { Ratio of net } \\
\text { return on } \\
\text { equity (\%) }\end{array}$ & $\begin{array}{c}\text { Gross } \\
\text { return on } \\
\text { assets (\%) }\end{array}$ & $\begin{array}{c}\text { Profitability } \\
\text { ratio of net } \\
\text { assets (\%) }\end{array}$ \\
\hline 2009 & 22.47 & 21.47 & 17.39 & 23.47 & 19.01 & 31.88 & 25.82 \\
\hline 2010 & 23.82 & 19.55 & 15.83 & 19.89 & 16.11 & 39.22 & 31.76 \\
\hline 2011 & 21.68 & 15.35 & 12.43 & 15.35 & 12.43 & 42.69 & 34.57 \\
\hline 2012 & 18.83 & 12.20 & 9.88 & 12.20 & 9.88 & 47.94 & 38.83 \\
\hline 2013 & 19.21 & 10.77 & 8.73 & 10.77 & 8.73 & 62.45 & 50.59 \\
\hline 2014 & 30.25 & 14.18 & 11.48 & 14.18 & 11.48 & 140.15 & 113.52 \\
\hline
\end{tabular}




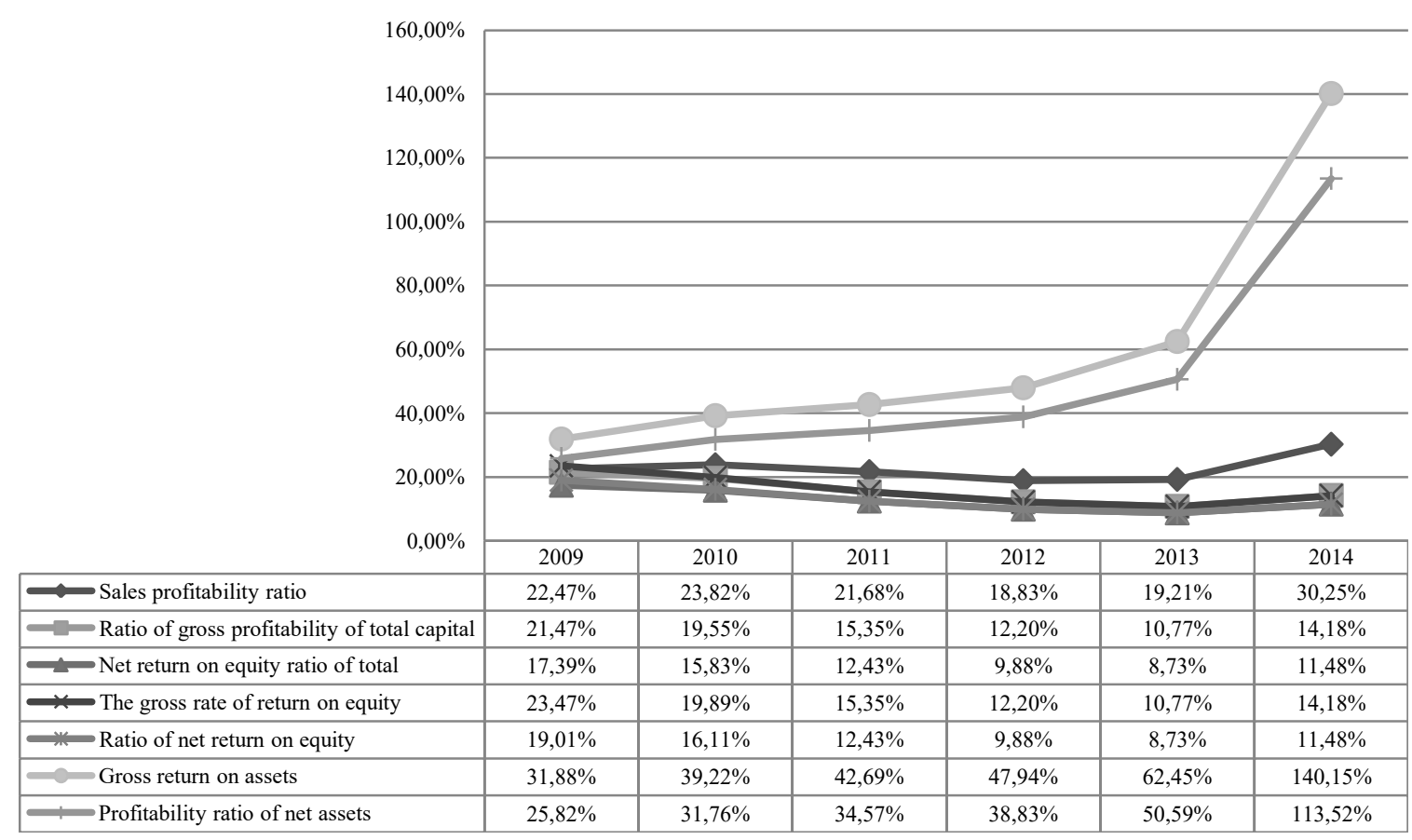

Figure 6. Comparable rate of profitability of the company ABC Transport (source: author's compilation)

The ABC company notes an increase in profitability despite the increase in fuel prices and road tolls. This is because the company implemented a new transport routes to new territories that previously were unsupported. Despite the fact that the loans amortised and the adjustment of the rolling stock to European requirements occurred, the company was capable of developing further. The ABC company can consider breakeven as a satisfactory result because the company shows a profit of $30 \%$ over the period of 5 years, based on the data from 2014.

\section{Conclusions}

The question raised in the article, despite its popularity and continuous research and analysis on the subject, is still valid. The term of market volatility of transport services through the prism of profitability of companies dictates the pace of development. Based on the data contained in the article, one can come to following conclusions:

1. The price of oil in world shaped fuel prices in the country.

2. Fuel prices in Poland shape the dynamics of changes in the market of road transport services.

3. The relation between the price of fuel and profitability are not only based on the nature of the transaction. The relation goes much further, because the prices also affect the pace of development and achieving a profit by the company.

4. The share of fuel prices in the profitability of companies is seen in the light of the overall costs of the company. The cost of fuel is estimated as approximately $50 \%$ of operating expenses.

5. Determination of the level of profitability, which the company considers to be satisfactory, requires the use of at least a few indicators, because changes occur during the course of actions aiming at achieving the goal.

6. Final profitability ratios should compare in similar period.

The topic of the fuel has been thoroughly investigated all over the world, including Poland. However, the savings and the cost reduction components have still many unexplored areas. Fuel price is dependent on external factors affecting the country like demand and supply; therefore, the reduction in fuel price is hard to achieve. Still, from a practical point of view, the price of fuel is an important factor that is stimulating development of the company. For that reason, the research in regards to the 
impact of the fuel prices should continue. However, the full exploration of the topic is still in a distant future.

\section{References}

Bednarski L.(2001), Analiza rentowności przedsiębiorstwa, W: Analiza Ekonomiczna Przedsiębiorstwa, L. Bednarski, R. Borowiecki, J. Duraj, E. Kurtys, T. Waśniewski, B. Wersty, Wydawnictwo Akademii Ekonomicznej im. Oskara Langego we Wrocławiu, Wrocław

Clerides, S., \& Zachariadis, T. (2008). The effect of standards and fuel prices on automobile fuel economy: an international analysis. Energy Economics, 30(5), 2657-2672

Engelhardt J. (2014), Zasady Analizy i oceny działalności gospodarczej przedsiębiorstw kolejowych, Wydawnictwo CeDeWu, Warszawa

Kurtys E. (1993), Analiza kosztów własnych przedsiębiorstwa, W: Analiza Ekonomiczna Przedsiębiorstwa, L. Bednarski, R. Borowiecki, J. Duraj, E. Kurtys, T. Waśniewski, B. Wersty, Wydawnictwo Akademii Ekonomicznej im. Oskara Langego we Wrocławiu, Wrocław

Mohammadi, H. (2009). Electricity prices and fuel costs: Long-run relations and short-run dynamics. Energy Economics, 31(3), 503-509

Nowak E. (2005), Analiza sprawozdań finansowych, Polskie Wydawnictwo Ekonomiczne S.A., Warszawa 2005

Od czego uzależnione są ceny paliw (2015) http://www.msfera.pl/od-czego-uzaleznione-sa-ceny-paliw-napolskich-stacjach-benzynowych.html

Olzacka B.( 2006), Analiza wyniku finansowego w wielkościach bezwzględnych i względnych, W: Analiza ekonomiczna w przedsiębiorstwie, M. Jerzemowska (red.), Polskie Wydawnictwo Ekonomiczne S.A., Warszawa

Osińska M. (2012), Zalewski W., Ekonometryczna analiza przychodów i kosztów w przedsiębiorstwie transportowym na tle koniunktury w branży, W: Logistyka 6

Podręcznik procedur kredytowych Banku X.y.z SA,( 2013) Warszawa 2013r

Sierpińska M. (2007), Jachna T., Metody podejmowania decyzji finansowych, analiza przykładów i przypadków, Wydawnictwo naukowe PWN, Warszawa

Skoczylas W.(2001), Wielokierunkowa ocena rentowności przedsiębiorstw, W: Analiza finansowa w zarządzaniu przedsiębiorstwem, E. Urbańczyk (red.), Wydawnictwo Naukowe Uniwersytetu Szczecińskiego, Szczecin

Sumaila, U. R., Teh, L., Watson, R., Tyedmers, P., \& Pauly, D. (2008). Fuel price increase, subsidies, overcapacity, and resource sustainability. ICES Journal of Marine Science: Journal du Conseil, 65(6), 832-840.

Szałucki K.(2005), Ekonomika Przedsiębiorstw Transportowych, W: Transport, W. Rydzykowski, K. Wojewódzka-Król (red.), Wydawnictwo Naukowe PWN SA, Warszawa

Stajniak M. (2008)Transport i spedycja Podręcznik do kształcenia w zawodzie technik logistyk, M. Staniak, M. Hajdul, M. Foltyński, A. Krupa, Wydawnictwo: Biblioteka Logistyka, Poznań

Transport wyniki działaności (2012 - 2015)

http://stat.gov.pl/cps/rde/xbcr/gus/tc transport_activity_results_in_2012.pdf 